With regard to the chemistry of the flowers themselves, little information is available in the literature. Maben ${ }^{9}$ reports a partial but non-illuminating proximate analysis of the "herb," which he speaks well of as an anthelmintic. His statement that the odor is due to a volatile oil is no doubt correct, although he reports no analysis to determine this. His conclusion that "the bitter principle which is probably of an alkaloidal nature, $* * *$ seems to be the active portion of the drug $* * *$," is also without foundation so far as his recorded data show. The flowers of our sample were more aromatic than those of either German or Roman chamomile; the aroma, however, was somewhat camphoraceous and lacked the sweetness and suggestion of amyl acetate ${ }^{10}$ which is especially pronounced in the flowers of Roman chamomile. The taste was strongly camphoraceous and was less bitter than that of Roman chamomile; in the latter respect it more nearly resembled the German. Whatever the real medicinal qualities of the flowers may be, their appearance, flavor and taste make it unlikely that the product will be accepted by the trade as a substitute for either German or Roman chamomile.

Pharmacognosy Laboratory,

BUREAU OF Chemistry.

\title{
POTENTIAL ACIDITY OF MILK AND A STANDARD METHOD FOR ITS DETERMINATION.
}

BY ROBERT WOOD TERRY.

Recently, during an investigation of the effect produced by the addition of the various alkalies to cows' milk, as practiced in infant feeding, a very peculiar phenomenon was noticed; namely, the acidity of milk is not proportionately reduced by the addition of water.

Chart A.-Quantity of $\frac{N}{10} \mathrm{NaOH}$ V.S. Required to Neutralize Fifteen Mils of Milk at DifFERENT DiLutions.

\begin{tabular}{cccccccc} 
& \multicolumn{7}{c}{ Mils $\frac{N}{10} \mathrm{NaOH}}$. \\
Percent milk. & 1. & 2. & 3. & 4. & Blank. & Average. & Acidity. \\
100 & 2.64 & 2.62 & 2.65 & 2.63 & 0.03 & 2.605 & 17.36 \\
75 & 2.50 & 2.47 & 2.49 & 2.49 & 0.03 & 2.460 & 16.40 \\
50 & $2.25^{2}$ & $2.3 \mathrm{I}$ & 2.33 & 2.34 & 0.03 & 2.300 & 15.33 \\
33.3 & $2.12^{2}$ & 2.18 & 2.21 & 2.24 & 0.04 & 2.170 & 14.46 \\
25 & $2.06^{2}$ & 2.14 & 2.14 & 2.14 & 0.04 & 2.100 & 14.00 \\
20 & $1.97^{2}$ & 2.07 & 2.02 & 2.06 & 0.05 & 2.000 & 13.33 \\
10 & $1.91^{2}$ & 1.96 & 1.95 & 1.97 & 0.12 & 1.840 & 12.26 \\
51 & 0.85 & 0.85 & 0.89 & 0.88 & 0.12 & 0.750 & 10.00 \\
1 & & & & & &
\end{tabular}

In one case, fifteen mils of milk required 2.60 mils of $\frac{N}{10} \mathrm{NaOH}$ for neutralization, whereas, fifteen mils of milk and fifteen mils of water only required

- Maben, "Note of Santolina chamaecyparissus," Pharm. J., 3, 16, 301, I885.

${ }_{10}$ The suggestion of amyl acetate, which has also been noted by Ballard (Loc. cit.) is probably not due to this substance, which has not been reported in the literature of Roman chamomile, but may probably be attributed to combinations of esters of angelic acid which are said to occur in the oil of Anthemis nobilis combined with butyl-, isoamyl-, isohexyl-alcohol, and anthemol. (Blaise, E. E., Bull. soc. chim., 29, 327, 1903, and Semmler, F. W., Die Atherischen Ole, I, 830-31,. I 905.) 
2.30 mils of $\stackrel{N}{10} \mathrm{NaOH}$. This phenomenon can be quickly demonstrated by titrating about ten mils of milk with lime water and phenolphthalein to a faint pink and then filling up the flask with carbon dioxide free water. Immediately the mixture assumes quite a deep shade of red. This effect on a titration is clearly shown in Chart "A."

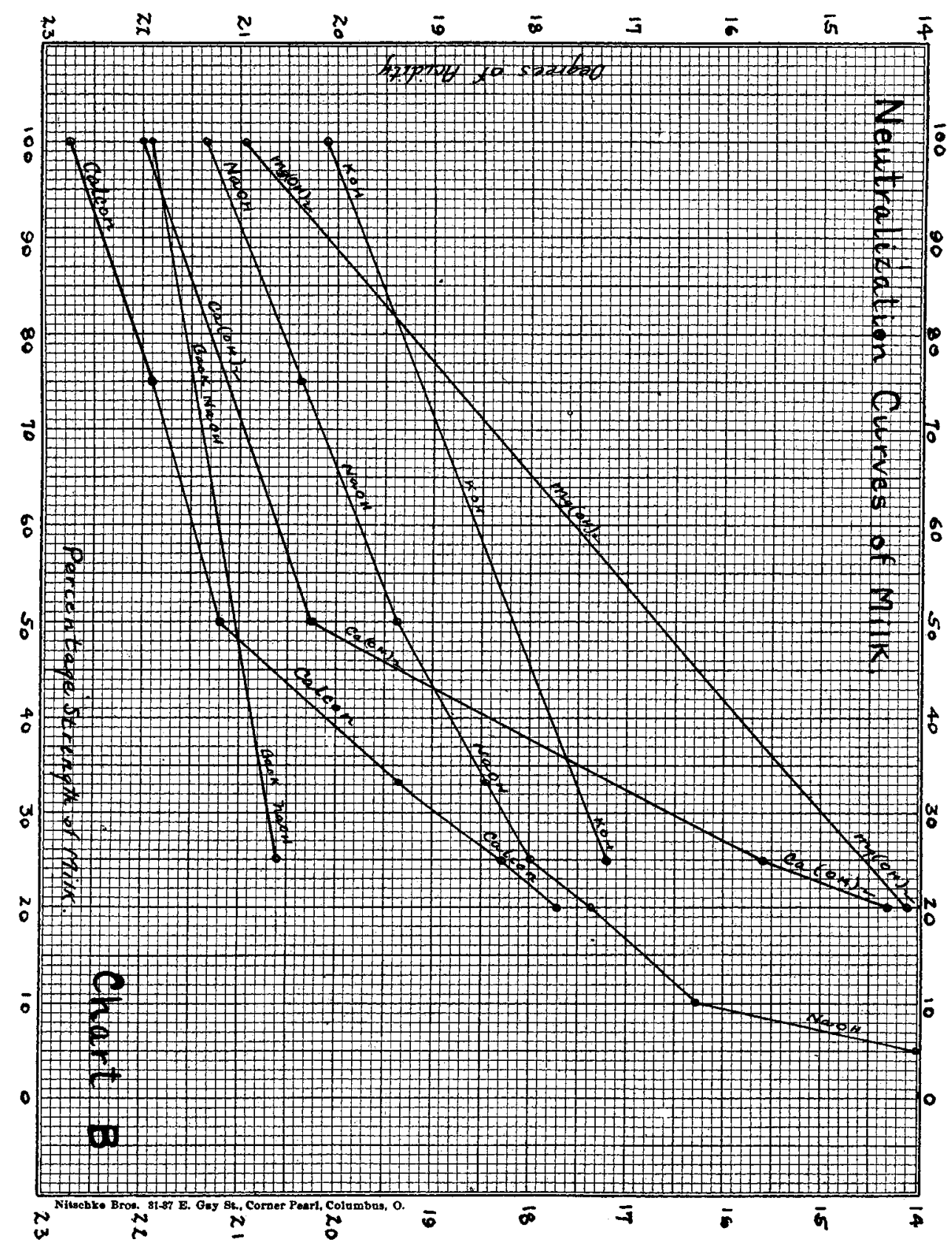


At first it was thought that this effect might be due to the obscurity of the endpoint, because of the opaqueness of the whole milk covering the pink phenolphthalein color. Titration in a dark room over an illuminated base gave practically identical results. A weak aqueous solution of red aniline was prepared and slowly added to ten mils of whole milk until the pink color was noticeable and this was repeated with ten mils of milk largely diluted. The amount required to produce a pink color was practically the same as with the whole milk, the difference being so small as to be negligible. Furthermore, the addition of water to whole milk and the aniline failed to increase the pink color as with milk and phenolphthalein. This shows that the phenomenon is not an optical one, such as end-point obscurity or the effect of complementary colors, especially so, since this same effect can be produced on colorless filtered whey, obtained by the action of rennin.

Although there are quite a few articles on milk acidity, a search of the literature revealed but two that mention or deal with this phenomenon and both of these were written about twenty-five years ago. No explanation of this phenomenon was offered by either investigator. ${ }^{1}$

Upon experimentation, the following facts were noticed:

I. No indicator except phenolphthalein is useful for determining milk acidity.

2. Titrations with normal and tenth-normal solutions do not give identical results.

3. Titrations with $\frac{N}{10} \mathrm{NaOH}$ and $\frac{N}{10} \mathrm{Ca}(\mathrm{OH})_{2}{ }^{a}$ do not give identical results.

4. A milk showing I8.75 degrees acidity with $\underset{10}{N} \mathrm{NaOH}$, gave by back titration 2 I.80 degrees acidity.

5. By direct titration twenty mils of milk ( 18.75 degrees acid) and o. Io gramme $\mathrm{CaCl}_{2} .2 \mathrm{H}_{2} \mathrm{O}$ showed 26.50 degrees acidity; back titration of same milk containing o. Io gramme $\mathrm{CaCl}_{2} .2 \mathrm{H}_{2} \mathrm{O}$ in twenty mils milk showed 27.55 degrees acidity.

6. Sodium citrate added to milk decreases its acidity.

7. Sodium oxalate acts in the same manner. A completely oxalated milk does not exhibit this phenomenon showing that calcium salts are either directly or indirectly responsible.

Chart "B" shows neutralization curves of the different alkalies at different dilutions of milk. The origin of each curve is correct except that of $\mathrm{KOH}$ and of $\mathrm{NaOH}$; these were raised so that all curves might be put on the one chart; the true origin of both of these is I 8 degrees acidity.

Most of these curves have only several determinations along the line because of the slowness of the work. The personal equation in milk titration is a large factor, so all titrations have to be performed by one operator, and each point must be the average of three or four closely agreeing results. Of course, this could be overcome by the use of a preserved milk, but it was thought best not to alter the milk in any form. The object of these curves was to furnish acidity factors for diluted milk feeding formulas, for which purpose they are more accurate than necessary.

a Sucrose solution. 


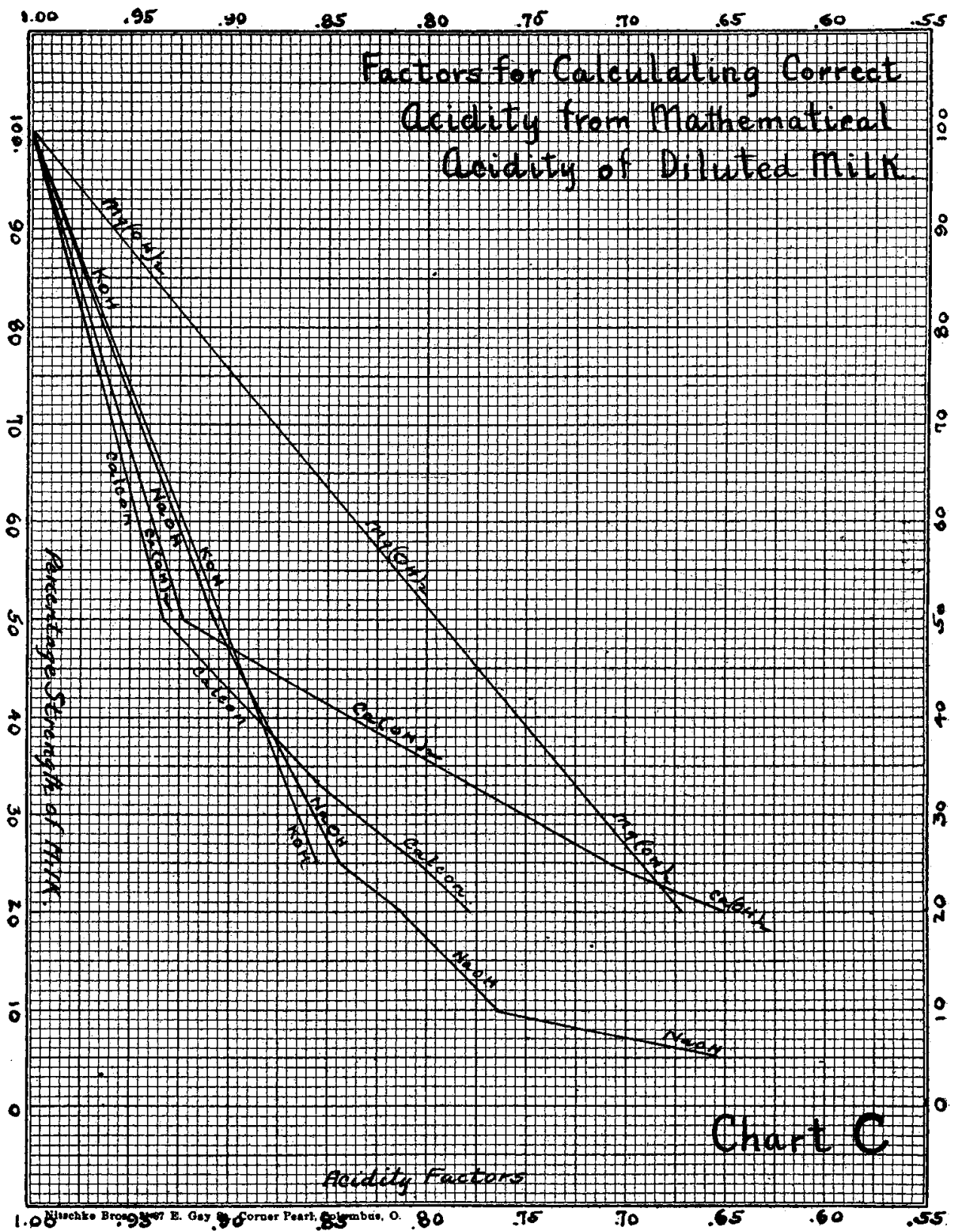

Chart " $\mathrm{C}$ " gives the factors for calculating the correct acidity of diluted milk mixtures by the use of the different alkalies. All that is necessary is to multiply the mathematical acidity by the factor for that strength milk.

Example: A physician desires to feed an infant a neutral milk mixture, consisting of

$$
\begin{aligned}
& \text { Milk................... ro ozs. } \\
& \text { Water.................. 20 ozs. }
\end{aligned}
$$

the mixture to be neutralized with milk of magnesia. 
The milk occupies $33.3 \%$ of the volume, therefore its original potential acidity has been mathematically reduced to 6 degrees (whole milk 18 degrees), but by consulting the factor table "Chart C," we find that the factor for milk of magnesia at $33.3 \%$ is 0.725 ; hence, the correct acidity of the mixture is $6 \times$ 0.725 , or 4.35 degrees. The physician then will add only the quantity of milk of magnesia required to neutralize 4.35 degrees instead of 6 degrees. The use of these factors is probably too complicated for every day use, but physicians usually have a set of pet formulas for which these factors could be calculated. The use of these tables would be essential in any clinical work upon the subject.

A large number of eliminative experiments were performed and numerous artificial wheys were made and finally it was determined that this phenomenon is due to the freshly precipitated tertiary calcium phosphate $\left(\mathrm{Ca}_{3}\left(\mathrm{PO}_{4}\right)_{2}\right)$ or possibly a mixture of the secondary salt $\left(\mathrm{CaHPO}_{4}\right)$ and the tertiary salt, but for convenience of expression it will be considered as being due to $\mathrm{Ca}_{3}\left(\mathrm{PO}_{4}\right)_{2}$ only. During a titration this substance is precipitated in a fine, almost colloidal state. Although this substance is but slightly soluble in water, its physical condition is such that it immediately saturates the fluid in which it is formed or any fluid which is added to it; especially is this so in the presence of citrates (normal constituents of milk), since it appears to be noticeably soluble in their presence. This phosphate hydrolyzes in water to produce an alkaline solution just as does its corresponding sodium salt, and of course only that which is in true solution can hydrolyze; hence, if one has a large volume of liquid in his titrating flask, naturally one will have more of the calcium phosphate in solution and therefore a larger amount of hydrolysis. This is the reason the end-point comes sooner in a diluted mixture. This theory can be demonstrated by titrating primary calcium phosphate $\left(\mathrm{Ca}\left(\mathrm{H}_{2} \mathrm{PO}_{4}\right)_{2}\right)$ with lime water and phenolphthalein to a faint pink and rapidly adding a large volume of distilled water $\left(\mathrm{CO}_{2}\right.$ free $)$; the resulting solution will be a fairly deep red. Add a few milligrammes of normal sodium citrate and immediately an intense red color results, showing that the corresponding sodium salt hydrolyzes to a larger extent than does the calcium salt or, that the citrate renders the calcium salt more soluble so that more hydrolysis takes place. The concentration of the primary calcium phosphate solution should be about that of milkten mils requiring about five mils of lime water. This may also be demonstrated by actual titration of this solution at different dilutions.

Solutions or suspensions of secondary calcium phosphate gradually. become acid on standing.

$$
\begin{aligned}
& \mathrm{CaHPO}_{4}+2 \mathrm{H}_{2} \mathrm{O} \rightleftharpoons \mathrm{Ca}(\mathrm{OH})_{2}+\mathrm{H}_{3} \mathrm{PO}_{4} \\
& 2 \mathrm{CaHPO}_{4}+\mathrm{Ca}(\mathrm{OH})_{2} \rightleftharpoons \mathrm{Ca}_{3}\left(\mathrm{PO}_{4}\right)_{2}+2 \mathrm{H}_{2} \mathrm{O} .
\end{aligned}
$$

This action is very slow because it has been shown that it requires many days to establish an equilibrium between a solid calcium phosphate and the solution with which it is in contact. ${ }^{2}$ That these equations are reversible may easily be demonstrated by titrating primary calcium phosphate to a faint pink with lime water and then adding boiling carbon dioxide free water; immediately the pink color disappears and the phosphates agglutinate in small floccules. Stopper the flask securely and place in cold water with occasional agitation; as soon as cool the solution will assume a fairly deep red color.

NorE.-Calcon is a proprietary preparation. 
Primary calcium phosphate was titrated with lime water to a faint pink and the proportions noted. Another lot was mixed in the same proportion but without the indicator. The proportions required fell between the theoretical amounts to produce $\mathrm{CaHPO}_{4}$ and $\mathrm{Ca}_{3}\left(\mathrm{PO}_{4}\right)_{2}$. The hydrogen-ion concentration of this solution and $\mathrm{a}$ one in five dilution of it were determined by Clark \& Lubs Colorimetric Method as described in the Journal of Bacteriology, January I9I 7.

The results are as follows:

FILTERED IMMEDIATELY.

$\left.\begin{array}{rr}\text { Ioo percent Solution } \mathrm{P}_{\mathrm{H}} & 7.2 \\ \text { 2o percent Solution } \mathrm{P}_{\mathrm{H}} & 8.0\end{array}\right\}$ Phenol red.

FILTERED AFTER 22 HOURS.

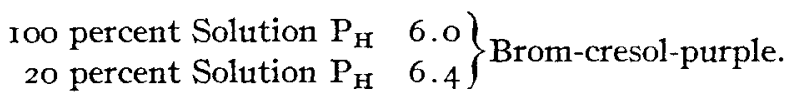

FILTERED AFTER 45 HOURS.

$\left.\begin{array}{rr}\text { Ioo percent Solution } \mathrm{P}_{H} & 5.6 \\ \text { 20 percent Solution } \mathrm{P}_{\mathrm{H}} & 6.2\end{array}\right\}$ Brom-cresol-purple.

From the above data it will be seen that the result of a milk acidity determination is entirely dependent upon conditions that do not affect other titrations, so that results of one chemist may not be comparable with those of another. One authority recommends diluting twenty-five mils of milk to half a liter and then titrating so that the end-point may be more clearly noticed! Another recommends boiling to drive out carbon dioxide!

Van Slyke and Bosworth ${ }^{3}$ have suggested a method of determining milk acidity by precipitating the calcium salts by the use of neutral potassium oxalate. This reduces the titratable acidity about one-half, eliminates the error due to dilution and produces a somewhat sharper end-point. Notwithstanding these advantages, the writer does not believe that it is exactly proper to denaturize the milk in this manner and then titrate. This method may be a good analytical procedure, but it does not give actual titratable acidity. If the soluble or suspended calcium salts play a rôle in the titration, then that factor should be considered in the titration. Particularly is this so in calculating milk acidity in infant feeding for the correct addition of alkalies. Although the feasibility of adding alkalies to cows' milk in infant feeding has been questioned by some authorities, it can be proven that it has a scientific as well as a practical basis.

Cows' milk has about six times the potential acidity of human milk. Bosworth ${ }^{4}$ has claimed that the addition of lime water to cows' milk is not necessary because the titratable acidity of oxalated cows' milk and human milk are about the same. If we will analyze titrations by $\frac{N}{10} \mathrm{NaOH}, \frac{N}{10} \mathrm{Ca}(\mathrm{OH})_{2}$ and of a completely oxalated rolution, these points will be more understandable.

First--Titration of $\mathrm{Ca}\left(\mathrm{H}_{2} \mathrm{PO}_{4}\right)_{2}$ with ${ }_{10}^{\mathrm{N}} \mathrm{Ca}(\mathrm{OH})_{2}$ - - As the calcium hydroxide is added the $\mathrm{Ca}_{3}\left(\mathrm{PO}_{4}\right)_{2}$ is precipitated. This is so slightly soluble in water that but little hydrolysis takes place. The deviation from the end-point as expressed by the following equation is probably due to the alkaline hydrolysis of the $\mathrm{Ca}_{3}\left(\mathrm{PO}_{4}\right)_{2}$ in solution. 


$$
\mathrm{Ca}\left(\mathrm{H}_{2} \mathrm{PO}_{4}\right)_{2} \cdot \mathrm{H}_{2} \mathrm{O}+{ }_{2} \mathrm{Ca}(\mathrm{OH})_{2}=\mathrm{Ca}_{3}\left(\mathrm{PO}_{4}\right)_{2}+{ }_{5} \mathrm{H}_{2} \mathrm{O} \text {. }
$$

Mol. $\mathrm{Ca}\left(\mathrm{H}_{2} \mathrm{PO}_{4}\right)_{2} \cdot \mathrm{H}_{2} \mathrm{O}$ requires 40 liters $\frac{N}{10} \mathrm{~V}$. S. Ca $(\mathrm{OH})_{2}$.

Theoretically. -25 mils $\mathrm{Mol} . / 2 \mathrm{O} \mathrm{Ca}\left(\mathrm{H}_{2} \mathrm{PO}_{4}\right)_{2} \cdot \mathrm{H}_{2} \mathrm{O}$ requires 50.00 mils ${ }_{10}^{N}$ $\mathrm{Ca}(\mathrm{OH})_{2}$.

Actually. -25 mils $\mathrm{Mol} . / 2 \mathrm{O} \mathrm{Ca}\left(\mathrm{H}_{2} \mathrm{PO}_{4}\right)_{2} \cdot \mathrm{H}_{2} \mathrm{O}$ requires 45.75 mils $\frac{N}{10} \mathrm{Ca}(\mathrm{OH})_{2}$.

Here it will be seen that the end-point comes before the above equation is completed, but long after the completion of an equation for the production of $\mathrm{CaHPO}_{4}$ (theoretically $25 \mathrm{mils}$ ). It will be noted that the end-point falls very near the $\mathrm{Ca}_{3}\left(\mathrm{PO}_{4}\right)_{2}$ end-point, but quite a distance from the $\mathrm{CaHPO}_{4}$ end-point. From this the writer believes that the $\mathrm{Ca}_{3}\left(\mathrm{PO}_{4}\right)_{2}$ end-point is the correct one and that any deviation from this is due to the alkaline hydrolysis of the $\mathrm{Ca}_{3}\left(\mathrm{PO}_{4}\right)_{2}$ rather than due to an acid hydrolysis from the $\mathrm{CaHPO}_{4}$ end-point; especially since this acid hydrolysis is very slow as compared with the almost instantaneous alkaline hydrolysis. Citric acid, a tribasic acid, produces an end-point with phenolphthalein at the formation of the normal salt. In the above equation practically all the $\left(\mathrm{PO}_{4}\right)$ is precipitated and incapable of hydrolysis.

Second-Titration of $\mathrm{Ca}\left(\mathrm{H}_{2} \mathrm{PO}_{4}\right)_{2}$ with ${ }_{10}^{N} \mathrm{NaOH}$.- In this case the deviation from the end-point as expressed by the following equation is due to the combined alkaline hydrolysis of the $\mathrm{Na}_{2} \mathrm{HPO}_{4}$ and the $\mathrm{Ca}_{3}\left(\mathrm{PO}_{4}\right)_{2}$.

${ }_{3} \mathrm{Ca}\left(\mathrm{H}_{2} \mathrm{PO}_{4}\right)_{2} \cdot \mathrm{H}_{2} \mathrm{O}+8 \mathrm{NaOH}=\mathrm{Ca}_{3}\left(\mathrm{PO}_{4}\right)_{2}+{ }_{4} \mathrm{Na}_{2} \mathrm{HPO}_{4}+\mathrm{I} \mathrm{I}_{2} \mathrm{O}$.

Here practically one-third of the $\left(\mathrm{PO}_{4}\right)$ is incapable of hydrolysis.

3 Mols. $\mathrm{Ca}\left(\mathrm{H}_{2} \mathrm{PO}_{4}\right)_{2} \cdot \mathrm{H}_{2} \mathrm{O}$ requires 80 liters of $\frac{N}{10} \mathrm{~V}$. S. NaOH.

Theoretically.-25 mils Mol./20 $\mathrm{Ca}\left(\mathrm{H}_{2} \mathrm{PO}_{4}\right)_{2} \cdot \mathrm{H}_{2} \mathrm{O}$ requires 33.33 mils ${ }_{10}^{N}$ $\mathrm{NaOH} . \quad\left(\mathrm{K}_{2} \mathrm{HPO}_{4}\right.$ and $\mathrm{Na}_{2} \mathrm{HPO}_{1}$ are slightly alkaline to phenolphthalein)

Actually.-25 mils Mol./20 Ca $\left(\mathrm{H}_{2} \mathrm{PO}_{4}\right)_{2} \cdot \mathrm{H}_{2} \mathrm{O}$ requires 31.35 mils $\frac{\mathrm{N}}{10} \mathrm{NaOH}$.

Third-Oxalated $\mathrm{Ca}\left(\mathrm{H}_{2} \mathrm{PO}_{4}\right)_{2}$ Titrated with $\frac{\mathrm{N}}{10} \mathrm{NaOH}$.-All the calcium salt has been precipitated by the oxalate-

$$
\mathrm{Ca}\left(\mathrm{H}_{2} \mathrm{PO}_{4}\right)_{2}+\mathrm{K}_{2} \mathrm{C}_{2} \mathrm{O}_{4}=2 \mathrm{KH}_{2} \mathrm{PO}_{4}+\mathrm{CaC}_{2} \mathrm{O}_{4} \text {. }
$$

Hence, one is now titrating primary potassium phosphate $\left(\mathrm{KH}_{2} \mathrm{PO}_{4}\right)$ instead of the primary calcium phosphate; thus:

$$
2 \mathrm{KH}_{2} \mathrm{PO}_{4}+2 \mathrm{NaOH}=\mathrm{K}_{2} \mathrm{HPO}_{4}+\mathrm{Na}_{2} \mathrm{HPO}_{4}+{ }_{2} \mathrm{H}_{2} \mathrm{O} \text {. }
$$

Mol. $\mathrm{Ca}\left(\mathrm{H}_{2} \mathrm{PO}_{4}\right)_{2} \cdot \mathrm{H}_{2} \mathrm{O}$ requires 20 liters $\frac{N}{10}$ V. S. NaOH.

Theoretically.-25 mils $\mathrm{Mol} . / 20 \mathrm{Ca}\left(\mathrm{H}_{2} \mathrm{PO}_{4}\right)_{2} \cdot \mathrm{H}_{2} \mathrm{O}+\mathrm{K}_{2} \mathrm{C}_{2} \mathrm{O}_{4}$ requires 25 .0o mils $\frac{N}{10} \mathrm{NaOH}$.

(minus)

Actually.-25 mils Mol./2O Ca( $\left.\mathrm{H}_{2} \mathrm{PO}_{4}\right)_{2} \cdot \mathrm{H}_{2} \mathrm{O}+\mathrm{K}_{2} \mathrm{C}_{2} \mathrm{O}_{4}$ requires $25 \cdot 35$ mils $\frac{N}{10} \mathrm{NaOH}$.

All the $\left(\mathrm{PO}_{4}\right)$ is in solution in this case. It will now be seen that the effect of the addition of potassium oxalate to milk before titration is that of converting insoluble compounds to soluble hydrolyzable compounds. This procedure does not seem logical to the writer.

Theoretically from these equations the volumes of alkali required are

$\begin{array}{lcc}\mathrm{Ca}(\mathrm{OH})_{2 .} & \mathrm{NaOH} . & \mathrm{NaOH}+\mathrm{K}_{2} \mathrm{C}_{2} \mathrm{O}_{4} . \\ \mathrm{I} 2 \mathrm{O} & 8 \mathrm{O} & 60\end{array}$

Actually they are

rog. 8

$75 \cdot 2$

60.8 
or raising the actual value of $\mathrm{Ca}(\mathrm{OH})_{2}$ (I09.8) to I20, the value of $\mathrm{NaOH}(75.2)$ is raised to 82.2 .

Due to the presence of citrates the relations of these two alkalies do not hold good for a milk titration. The effect of citrates is as follows:

25 mils Mol. $/ 20 \mathrm{Ca}\left(\mathrm{H}_{2} \mathrm{PO}_{4}\right)_{2} \cdot \mathrm{H}_{2} \mathrm{O}+0.300 \mathrm{Na}_{3} \mathrm{C}_{6} \mathrm{H}_{5} \mathrm{O}_{7} .2 \mathrm{H}_{2} \mathrm{O}=39.9$ mils $\frac{N}{10}$ $\mathrm{Ca}(\mathrm{OH})_{2}$.

25 mils Mol. $/ 20 \mathrm{Ca}\left(\mathrm{H}_{2} \mathrm{PO}_{4}\right)_{2} \cdot \mathrm{H}_{2} \mathrm{O}+0.300 \mathrm{Na}_{3} \mathrm{C}_{6} \mathrm{H}_{5} \mathrm{O}_{7} \cdot 2 \mathrm{H}_{2} \mathrm{O}=30.05$ mils $\frac{N}{10}$ $\mathrm{NaOH}$.

Raising the value of $\mathrm{Ca}(\mathrm{OH})_{2}(39.9)$ to I $_{20}$ then the value of $\mathrm{NaOH}(30.05)$ is 90.3 .

As before stated, the writer believes, in any titration of milk, the effect of the calcium salts and citrates on the alkali used should be measured; this is, however, not possible on an oxalated milk. By doubling the value of an oxalated milk titration one is given correct theoretical results; but here again it is not actual potential acidity. Direct titration with $\frac{N}{10} \mathrm{Ca}(\mathrm{OH})_{2}$ gives results that are close to the theoretical results but it is thought not wise to adopt this alkali in a standard method as it is difficult to make and is not available as is the sodium solution. Results of any milk titration are only comparable with those of the same titration technic. Practically all the books, when referring to the degree of milk acidity, refer to that acidity which has been determined by sodium or potassium hydroxide so that the adoption of a calcium standard would raise these figures and probably cause some confusion.

Clark $^{5}$ has based his deductions on the inadvisability of adding lime water to cows' milk, on electrometric measurements of hydrogen-ion concentrations of cows' milk, human milk, and cows' milk and lime water, as follows:

Davidsohn. ${ }^{6}$.

Cows' milk $\mathrm{P}_{\mathrm{H}}=6.57$ or $\left.\mathrm{C}_{\mathrm{H}} 2.69 \times \mathrm{IO}^{-7}\right\}$

Human milk $\mathrm{P}_{\mathrm{H}}=6.97$ or $\left.\mathrm{C}_{\mathrm{H}} \mathrm{I} .07 \times 1^{-7}\right\} 18$ degrees $\mathrm{C}$.

Clark. ${ }^{5}-$

$\left.\begin{array}{l}\text { Cows' milk } \mathrm{P}_{\mathrm{H}}=6.5^{8} \text { or } \mathrm{C}_{\mathrm{H}} 2.60 \times 10^{-7} \\ \text { Human milk } \mathrm{P}_{\mathrm{H}}=7.22 \text { or } \mathrm{C}_{\mathrm{H}} 0.60 \times \text { 10 }^{-7}\end{array}\right\} 30$ degrees $\mathrm{C}$.

Clark finds that when cows' milk is modified under certain conditions with distilled water, the values are

$$
\mathrm{P}_{\mathrm{H}}=6.90 \text { or } \mathrm{C}_{\mathrm{H}} \mathrm{I} .2 \times \mathrm{IO}^{--7} \text {. }
$$

While modified under the same conditions plus $5 \%$ of lime water, the values are

$$
\mathrm{P}_{\mathrm{H}}=7.3^{6} \text { or } \mathrm{C}_{\mathrm{H}} 0.43 \times \mathrm{IO}^{-7} \text {. }
$$

The hydrogen-ion concentration of milk or milk mixtures may, to a limited extent, influence the velocity of the function of rennin, that is, the conversion of caseinogen to paracasein, but this has little, if anything, to do with the conversion of paracasein to calcium paracaseinate (true milk curds). The velocity of this change is a function of potential calcium ionization and potential calcium ionization is a function of potential acidity. Upon the rate of formation of the calcium paracaseinate depends its physical condition; the more rapidly it is formed, the more tough, impenetrable and indigestible it is. By the proper reduction of potential acidity, the curd (calcium paracaseinate) of cows' milk is precipitated 
in a physical condition resembling the curd of human milk-soft. flocculent and readily digestible. 'This is the desideratum in adding alkalies to cows' milk in artificial infant feeding.

The above theory regarding milk coagulation and its alteration by alkalies has been worked out by the writer during some research work on this subject and this theory will be explained in detail in an article now in preparation.

From the above it will be apparent that a correct and uniform method of determining potential milk acidity and its proper reduction is of value, particularly in infant feeding.

For the sake of uniformity, the writer suggests the following method for determining milk acidity, which, if followed, will produce results that are comparable with other laboratories or chemists. It is hoped that this will be adopted as a standard method.

\section{STANDARD METHOD FOR DETERMINING MILK ACIDITY.}

Pipette ro mils of milk into an Erlenmeyer flask of about roo mils total capacity and add 5 drops of a $\mathrm{I}$ percent alcoholic solution of phenolphthalein. Titrate slowly to the first noticeable pink tint that is permanent for one minute. This is to be determined by comparing with a flask of the same shape and capacity and containing the same amount of milk; $\frac{N}{10} \mathrm{NaOH} \mathrm{V.S.} \mathrm{is} \mathrm{to} \mathrm{be} \mathrm{used} \mathrm{in} \mathrm{the}$ titration. One mil of $\frac{N}{10} \mathrm{NaOH}$ represents Io degrees of acidity. The titration is to be performed only in daylight. No water should be added before or during the titration.

NOTES ON THE PROCESS.

I. The titrating flask should be dry or containing, at the most, only a couple drops of water.

2. Exactly 5 drops of the indicator should be used as it has been shown by Hopkins and Powers ${ }^{1}$ that this also affects the end-point.

3. The $\mathrm{NaOH}$ solution should be $\frac{N}{10}$ and should be as free from carbonates as possible but should not be prepared by using barium hydroxide. It is preferably standardized against purified potassium bitartrate as described in the United States Pharmacopoeia IX.

4. This concentration of alkali and milk and the conditions named give the best end-point excepting oxalated milk, so that nothing is gained by using a larger volume of milk. Some writers recommend 5 o or 100 mils of milk as a sample and titrate with $\frac{N}{10}$ V.S. This large volume of milk renders the color changes so sluggish that a definite end-point cannot be noticed. This same dropwise effect can be produced by using 25 mils of milk and $\frac{N}{4}$ alkali or roo mils of milk and $\frac{N}{1}$ alkali, but the results are not the same as with Io mils of milk and $\frac{N}{10}$ alkali which is shown as follows:

a. Io mils and $\frac{N}{10}$ alkali-milk occupies 84.75 percent of volume in flask at end-point-acidity 18 degrees.

b. 25 mils of milk and $\frac{N}{4}$ alkali-milk occupies 93.3 percent of volume in flask at end-point-acidity i 8.3 degrees. $^{a}$

c. roo mils milk and ${ }_{1}^{N}$ alkali-milk occupies 98.4 percent of volume in flask at end-point-acidity 18.5 degrees. $^{a}$ 
This shows how necessary it is that the above method should be followed in detail to obtain correct results.

5. The writer uses for these determinations an especially constructed burette of 5 mils' capacity; the graduated part of the burette is about 230 millimeters in length so that a reading of 0.02 mils can be made with accuracy. The burette delivers 5 drops to the $0.1 \mathrm{mil}$. This type of burette is strongly recommended and it may be constructed from a graduated pipette. It is filled from the bottom by applying suction to a rubber tube attached to the top.

6. One must not confuse an acidity degree as determined by this method with the Soxhlet-Henkel degree, referred to principally in German literature. This German degree is two and a half times as great. Quite often dairymen determine milk acidity as lactic acid-ten mils milk titrated with ${ }_{10}^{N} \mathrm{NaOH}$ and the result multiplied by 0.9 . As the acidity of fresh milk is not due to lactic acid, but principally to acid phosphates, this degree is confusing and should be discontinued.

Columbus, Ohro,

363 KING Ave.,

JUNE 6, 1919.

\section{BIBLIOGRAPHY.}

I. Van Slyke, L. L., Proc. A. O. A. C., I893, I17; Hopkins, C. G., and Powers, W. A., Proc. A. O. A. C., $1895, \mathrm{1} 25$.

2. Cameron and Hurst, J. Am. Chem. Soc., 1904, 26, 905; Cameron and Bell, U. S. Dept. Agr., Bureat Soils, Bull. 4r, I907.

3. Van Slyke and Bosworth, Bull. 37, N. Y. Expt. Sta., Geneva, 1914.

4. Bosworth, A. W., J. Biol. Chem., 1915, 20-707.

5. Clark, W. M., J. Med. Research, 1915, 31-431.

6. Davidsohn, H., 2 Kinderheilk, 9, I I-8.

\section{A COMPARISON OF METHODS FOR THE DETERMINATION OF ETHYL,} ALCOHOL IN FERMENTED LIQUORS.*

\section{BY CHARLES H. ROGERS.}

Four methods have been recommended for the determination of the percentage of ethyl alcohol by weight and by volume in fermented liquors.

Metrod I. By Evaporation.-Determine the specific gravity of the sample at $\frac{15.6^{\circ}}{15.6^{\circ}} \mathrm{C}$. Carefully pour 50 or, preferably, roo mils of the sample to be examined into a porcelain evaporating dish and evaporate to about one-fourth of the original bulk. Make up to the original volume with distilled water and determine the specific gravity at $\frac{15 \cdot 6^{\circ}}{15.6^{\circ}} \mathrm{C}$. of this second or de-alcoholized portion. Add the figure $I$ to the original specific gravity, and from this subtract the second specific gravity. The difference will be the specific gravity corresponding to the alcohol in the sample. The percentage is found by consulting the specific gravity and percentage alcohol table in the Pharmacopoeia.

* Read before Northwestern Branch A. Ph. A. and Scientific Section Minnesota Pharmaceutical Association. 